Communication

\title{
Biophysical Properties and Antiviral Activities of Measles Fusion Protein Derived Peptide Conjugated with 25-Hydroxycholesterol
}

\author{
Bárbara Gomes $^{1}$ (D), Nuno C. Santos ${ }^{1, *}$ and Matteo Porotto ${ }^{2,3, *}$ \\ 1 Instituto de Medicina Molecular, Faculdade de Medicina, Universidade de Lisboa, Av. Prof. Egas Moniz, \\ 1649-028 Lisbon, Portugal; bgomes@fm.ul.pt \\ 2 Center for Host-Pathogen Interaction, Columbia University Medical Center, 701 W. 168th St., New York, \\ NY 10032, USA \\ 3 Department of Pediatrics, Columbia University Medical Center, 701 W. 168th St., New York, NY 10032, USA \\ * Correspondence: nsantos@fm.ul.pt (N.C.S.); mp3509@cumc.columbia.edu (M.P.); \\ Tel.: +351-21-799-9480 (N.C.S.); +1-212-305-4522 (M.P.)
}

Received: 13 July 2017; Accepted: 26 October 2017; Published: 31 October 2017

\begin{abstract}
Measles virus (MV) infection is re-emerging, despite the availability of an effective vaccine. The mechanism of MV entry into a target cell relies on coordinated action between the MV hemagglutinin $(\mathrm{H})$ receptor binding protein and the fusion envelope glycoprotein $(\mathrm{F})$ which mediates fusion between the viral and cell membranes. Peptides derived from the $C$-terminal heptad repeat (HRC) of F can interfere with this process, blocking MV infection. As previously described, biophysical properties of HRC-derived peptides modulate their antiviral potency. In this work, we characterized a MV peptide fusion inhibitor conjugated to 25-hydroxycholesterol (25HC), a cholesterol derivative with intrinsic antiviral activity, and evaluated its interaction with membrane model systems and human blood cells. The peptide (MV-HC) has a $90 \%$ inhibitory concentration $\left(\mathrm{IC}_{90}\right)$ several logs more advantageous than the equivalent peptide bearing a polyethylene glycol (PEG)-cholesterol moiety. In membrane interaction studies, MV-HC shows a preference for pure 1-palmitoyl-2-oleoyl-sn-glycero-3-phosphocholine (POPC) monolayers and membranes rich in sphingomyelin, and interacts less with POPC:cholesterol membranes. MV-HC tends to self-aggregate in aqueous solution, in a concentration-dependent manner. Our results suggest that increased membrane interaction dynamicity results from $25 \mathrm{HC}$ conjugation, with a concomitant increase in peptide antiviral efficacy.
\end{abstract}

Keywords: measles virus; fusion; peptide; 25-hydroxycholesterol

\section{Introduction}

Measles virus (MV) is a human virus of the Paramyxoviridae family and Morbillivirus genus [1]. Despite the availability of a vaccine since 1963 and safe and effective immunization since the early 1980s, with a global drop in prevalence [2], measles is currently re-emerging and several recent outbreaks have occurred in developed countries. In the US, there were more than 600 measles cases in 2014, followed by the first measles-related death in the US in the last 12 years [3]. In 2017, outbreaks have also occurred in Romania and Italy [4]. Infections are mostly associated with vaccine refusal, but also occur in vaccinated persons exposed to this highly transmissible virus, and in the growing population of immunocompromised individuals [5]. The immune response elicited by vaccination varies widely within the population, the recommended two doses of vaccine are not a guarantee of an adequate protection [6,7], and immunocompromised people cannot be vaccinated with this live virus vaccine. The illness can be severe and lead to neurological sequelae, either immediately following infection or 
years later. Central nervous system (CNS) complications may occur soon after acute MV infection in the case of acute encephalomyelitis (AME), or years after infection, as a result of viral persistence in subacute sclerosing panencephalitis (SSPE). SSPE has recently been discovered to be more common than previously thought and may occur in up to one in 600 children infected under one year of age [8]. Despite presumably functional cell-mediated immunity and high antiviral antibody titers, immune control of CNS infection is not achieved in patients suffering from SSPE. The third form of MV-induced CNS disease-progressive infectious encephalitis or measles inclusion body encephalitis (MIBE)—occurs in immunosuppressed patients several months following MV infection [9-11]. There are no specific therapies for acute complications of MV or for persistent MV CNS infections [12-16].

Measles virus is an enveloped particle of approximately $200 \mathrm{~nm}$, with the surface glycoproteins that mediate viral attachment and entry (hemagglutinin, $\mathrm{H}$, and fusion, F) protruding from the cell-membrane derived lipid envelope, and the matrix proteins $(\mathrm{M})$ lining the inner surface. The viral core is composed of the negative-sense RNA genome packaged with the nucleoprotein $(\mathrm{N})$, large polymerase protein $(\mathrm{L})$ and polymerase-associated protein $(\mathrm{P})$ to form the replication complex. Entry of virus into a human cell and, presumably, cell-to-cell spread of virus generally requires interaction of the viral receptor binding protein $(\mathrm{H})$ with host cellular receptor(s). Wild-type (wt) MV infection starts in the respiratory tract. Alveolar macrophages and dendritic cells are the primary targets [17-20]. Binding of the $\mathrm{H}$ protein to CD150 leads to initial infection. The first MV-infected cells then transmit the virus to bronchus-associated lymphoid tissues and/or draining lymph nodes, where the virus proliferates in B and T lymphocytes (that also express CD150), and viremia ensues $[17,21]$. The adherens junction protein PVRL4 (or nectin-4) [22-27] has been identified as a MV receptor on the basolateral surface of respiratory epithelial cells, associated with viral transmission at later stages of pathogenesis $[21,26]$ as an exit receptor [28-31].

The $\mathrm{H}$ and $\mathrm{F}$ envelope glycoproteins work together to mediate virus attachment and entry into target cells. We refer to the H/F pairs of MV as the viral "fusion machinery" since these proteins, in the wt virus, act in concert. $\mathrm{F}$ is synthesized as a precursor $\left(\mathrm{F}_{0}\right)$ that is cleaved within the cell to yield the pre-fusion $\mathrm{F}$ complex comprising three $\mathrm{C}$-terminal $\mathrm{F}_{1}$ subunits linked covalently by disulfide bonds with three $\mathrm{N}$-terminal $\mathrm{F}_{2}$ subunits. This trimeric $\mathrm{F}$ structure is kinetically trapped in a metastable conformation; the pre-fusion state is maintained only in the absence of activation by $\mathrm{H}$ or high temperature. Fusion activation occurs when $\mathrm{H}$, upon engagement by a cell surface receptor (either CD150 or nectin-4, as discussed above), activates F [22-27]. After activation by $\mathrm{H}$, the pre-fusion $\mathrm{F}$ undergoes a structural transition, extending and inserting its hydrophobic "fusion peptide" into the target membrane. During entry, F refolds into a "trimer of hairpin" post-fusion structure that brings together the $N$-terminal heptad repeat (HRN) and the C-terminal heptad repeat (HRC), and the viral and cell membranes fuse [32-39].

We and others have shown that peptides derived from the HRC region of the $\mathrm{F}_{2}$ ectodomain inhibit paramyxovirus entry with varying activity [35,40-50]. We have previously identified the antiviral activity of short peptides (36 amino-acid residues) corresponding to the HRC domain of paramyxovirus $\mathrm{F}$.

We have shown that the peptides' potency is determined by two factors: the strength of the peptide's association with the corresponding HRN domain of the target fusion protein [49], and the kinetics of $\mathrm{F}$ activation by the virus' attachment protein [51]. By targeting lipid-conjugated fusion inhibitory C-peptides to the plasma membrane, where fusion occurs, and by engineering peptides with increased HRN-HRC-peptide binding affinity, we have enhanced the antiviral potency of our prototype inhibitors by a factor of several logs [40,52-54]. Using lipid conjugation to increase the inhibitors' half-life in vivo [53] and polyethylene glycol (PEG) linkers between the lipid moiety and the peptide, we further augmented potency and broad-spectrum activity [53]. For example, a specific HPIV3-derived, cholesterol-conjugated peptide is highly effective treatment for both the lethal encephalitis caused by the generally fatal paramyxovirus Nipah virus and for HPIV3 infection in vivo $[53,55,56]$. 
We have previously shown that specific biophysical properties of the HRC-derived peptides modulate their antiviral potency [56,57]. Specifically, we found that increasing the PEG linker length between the peptide and the cholesterol moiety led to a more dynamic interaction with model membranes, likely by decreasing the local hydrophobicity, and that this effect correlated with enhanced efficacy [56]. We therefore aimed to identify lipid modifications that would retain the anchoring property provided by cholesterol but increase the dynamicity of interaction with the membrane by being more hydrophilic. To this end, we evaluated a MV peptide fusion inhibitor derived from the HRC domain of MV F, conjugated to 25-hydroxycholesterol (25HC) without a PEG linker (Figure 1). $25 \mathrm{HC}$ is an oxysterol cholesterol derivative described in recent studies [58-61], more hydrophilic than cholesterol. To evaluate the potential of this conjugate, referred to as "MV-HC", as an MV antiviral, we assessed its aggregation behavior and its interaction with biomembranes and human blood cells, since we have shown these properties to predictably correlate with antiviral effects [57].

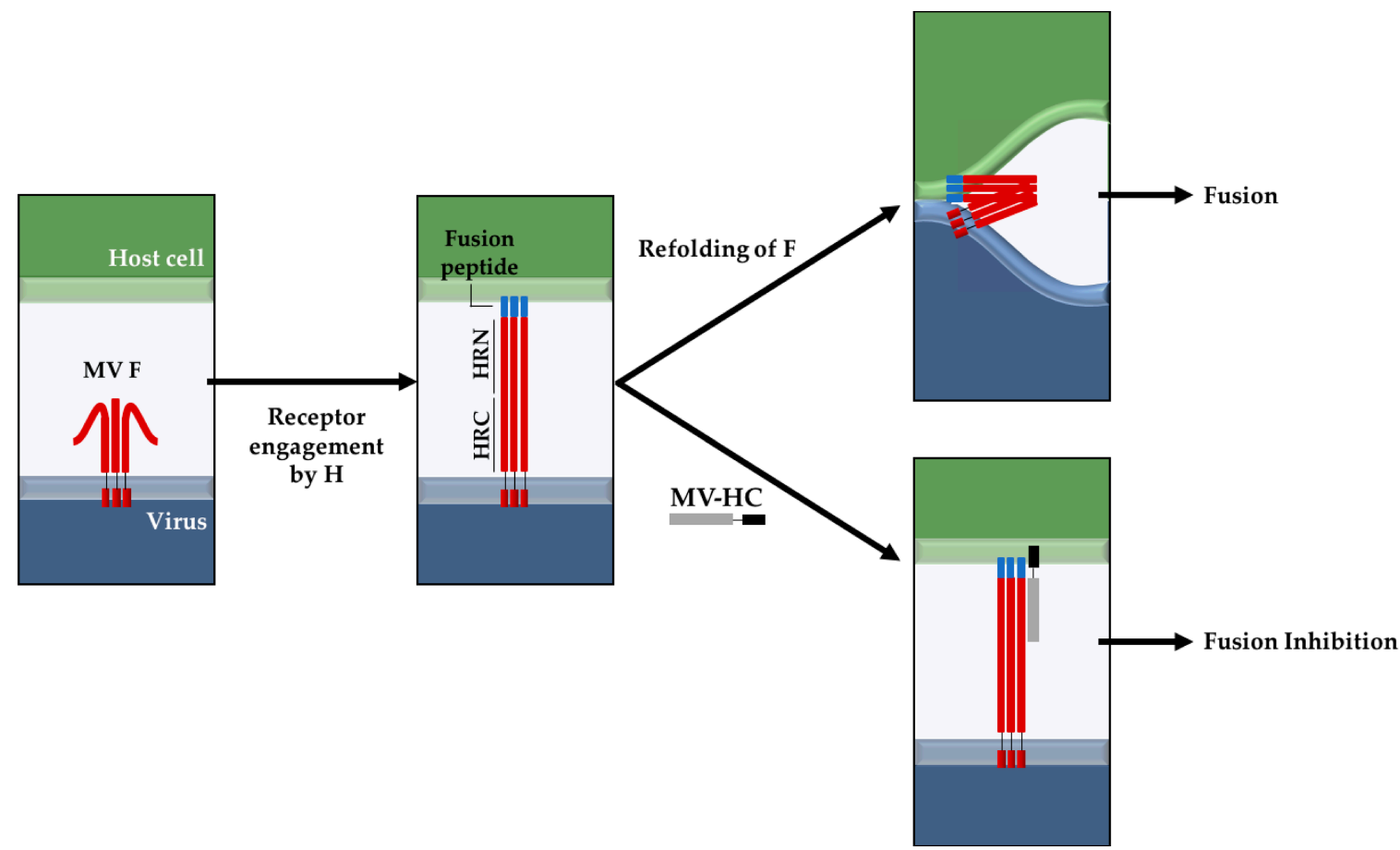

Figure 1. Proposed fusion inhibition mechanism of the MV-HC peptide. Peptides derived from the $\mathrm{HRC}$ domain of $\mathrm{F}$ can potently inhibit MV infection by binding to the HRN domain, after the fusion peptide inserts into the target cell, preventing the fusion between viral and cell membranes (adapted from $[37,53])$. For the sake of simplicity, the H protein is not represented in the diagram. The HRN and HRC domains, as well as the MV-HC peptide, are not represented up to scale relative to the full length of the protein or the thickness of the bilayer.

\section{Results}

\subsection{Interaction with Small Unilamellar Vesicles}

Kinetic profiles (sensorgrams) of peptide binding to small unilamellar vesicles (SUV) surfaces were acquired using surface plasmon resonance (SPR), which allows real-time detection of bound molecules on a SUV-covered surface [62] (Figure 2). Each sensorgram is composed of sequential binding and unbinding phases, corresponding to the sample injection over the lipid surface, followed by the removal of bound sample molecules through solvent flow. Three different membrane compositions were tested for their peptide binding, to mimic the liquid disordered domains containing 1-palmitoyl-2-oleoyl-sn-glycero-3-phosphocholine (POPC) and liquid ordered domains 
from mammalian cell membranes, with POPC and cholesterol (Chol), as well as lipid rafts containing sphingomyelin (SM) (POPC:Chol:SM), since it has been suggested that MV virions emerge from cholesterol rich-domains, such as lipid rafts $[63,64]$, and may retain this lipid composition in the viral envelope. SUV stability and size distribution were evaluated by dynamic light scattering (DLS), using a Malvern Zetasizer NanoZS (Malvern Instruments, Malvern, UK), guaranteeing a homogeneous vesicle size distribution regardless of lipid composition.
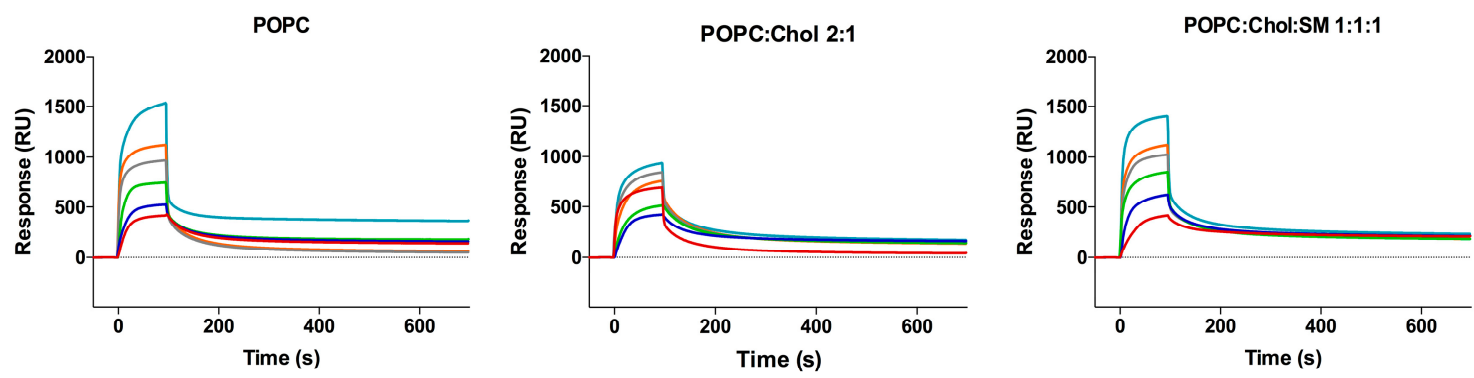

$$
-1 \mu \mathrm{M}-5 \mu \mathrm{M}-10 \mu \mathrm{M}-15 \mu \mathrm{M}-20 \mu \mathrm{M}-30 \mu \mathrm{M}
$$

Figure 2. Evaluation of MV-HC peptide interaction with membranes. SPR sensorgrams obtained for MV-HC in the presence of POPC, POPC:Chol = 2:1 or POPC:Chol:SM = 1:1:1 membranes $(1 \mathrm{mM})$. A range of peptide concentrations $(1-30 \mu \mathrm{M})$ was injected over the deposited vesicles.

MV-HC sensorgrams showed an interaction for all membranes tested (Figure 2). The highest level of binding and subsequent unbinding was observed for POPC vesicles, indicating a higher affinity of the peptide for disordered domains and dynamic unbinding. The addition of cholesterol decreases this interaction and unbinding, but the dynamicity increases in the presence of SM. The interaction between the conjugated peptide and the lipids is transient: the peptide binds to the lipid surface through a fast process, slowing down significantly until the end of peptide injection. Almost all peptide is removed during the unbinding phase, following a similar pattern, with a rapidly decreasing signal. Based on the maximum peptide binding and SUV deposition response, the respective average peptide-to-lipid molar ratios were calculated and plotted as a function of the injected peptide concentration (Figure 3).

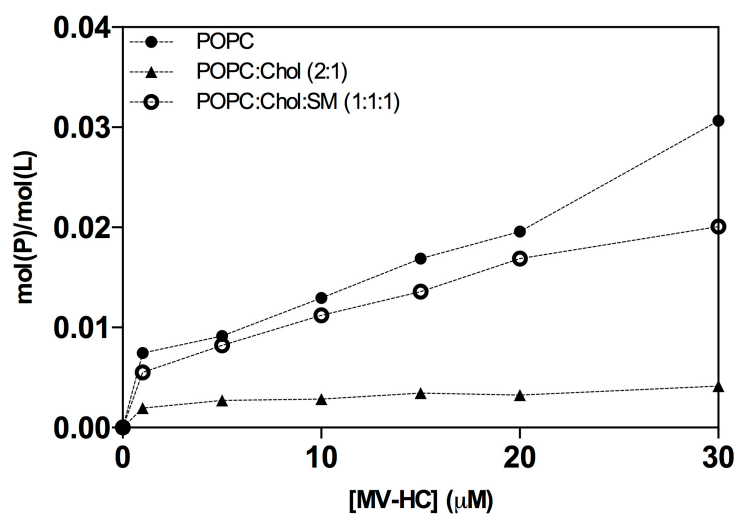

Figure 3. Average peptide-to-lipid ratios $(\mathrm{mol}(\mathrm{P}) / \mathrm{mol}(\mathrm{L}))$. The ratios were calculated using the sensorgrams' maximum binding response, as a function of peptide concentration, for its interaction with deposited POPC (solid circles), POPC:Chol (2:1) (solid triangle) and POPC:Chol:SM (1:1:1) (open circle) SUV. Peptide binding and SUV capture response values were retrieved from individual sensorgrams at specific reporting time points. Molar ratio values were calculated based on the relationship 1 RU to 1 $\mathrm{pg} / \mathrm{mm}^{2}$ of bound peptide or lipid [65].

The data in Figure 3 show a general increase in binding concomitant with increasing proportions of peptide. As seen in the sensorgrams, there is a significant interaction between the peptide and the 
POPC membranes. A weaker interaction was obtained for the POPC:Chol = 2:1 mixture, possibly explaining the dynamic behavior seen with this conjugate. In the presence of SM, the peptide's interaction increases, suggesting that membranes bearing both cholesterol and SM interact well with the peptide conjugate, with very fast binding and unbinding processes.

\subsection{Interaction with Blood Cells}

Erythrocytes and peripheral blood mononuclear cells (PBMC) were selected as cell models for assessing peptide-cell membrane affinity, and the lipophilic fluorescent probe di-8-ANEPPS was used as an indirect reporter of peptide-lipid interaction. Erythrocytes were chosen for study as a potential carrier for antiviral peptides during measles viremia (virus circulating in the blood stream) and PBMC are important since MV targets these cells after the initial respiratory phase. MV-HC was incubated with the two cell types at a range of concentrations for $1 \mathrm{~h}$. This peptide interacts with both types of cell, as shown by the dipole potential decrease in the presence of the peptide (Figure 4a). As a quantitative measure of the interaction of MV-HC with membranes, the intensity ratio was calculated for each peptide concentration. A decrease in ratio values indicates an increase in peptide interaction, concomitant with the increasing concentrations of peptide (Figure $4 \mathrm{~b}$ ). The affinity is higher when compared to sifuvirtide, very similar to that obtained for enfuvirtide, and slightly lower than that for T-1249, three viral fusion inhibitory peptides analyzed in previous studies that target human immunodeficiency virus (HIV) [66,67]. Compared with other viral fusion inhibitory peptides that bear a lipid moiety [68,69], the results in Figure 4 show a lower interaction between MV-HC and the two cell types.

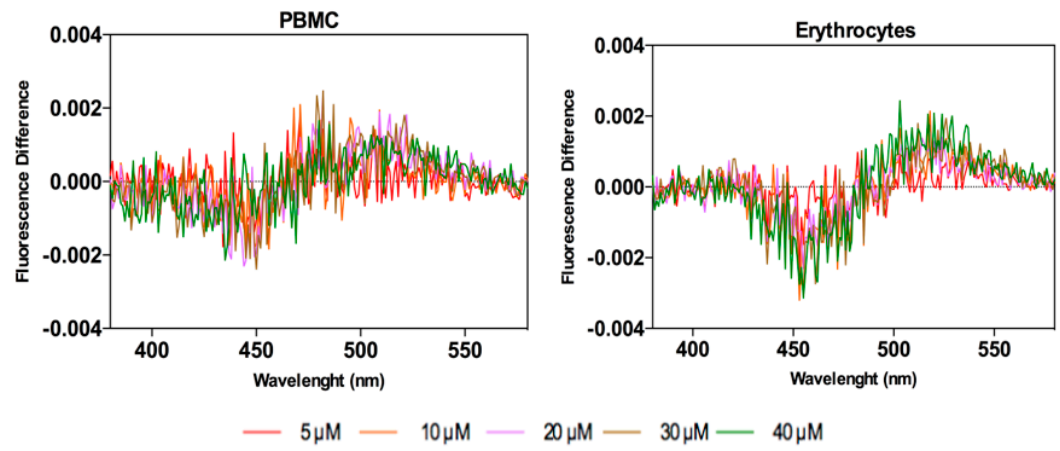

(a)

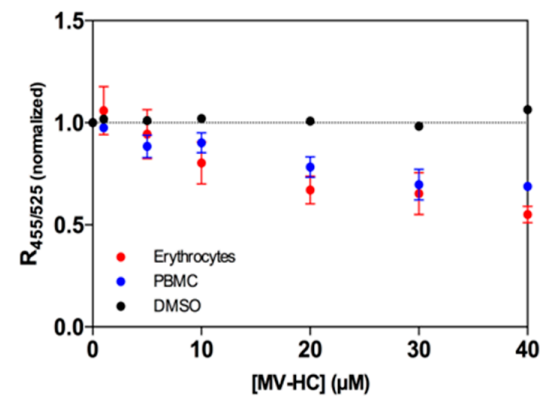

(b)

Figure 4. Peptide affinity towards erythrocytes and PBMC assessed by di-8-ANEPPS fluorescence: (a) Differential spectra of di-8-ANEPPS bound to cells in the presence of a range of concentrations of MV-HC. Spectra were obtained by subtracting the excitation spectrum (normalized to the integrated areas) of labeled cells in the absence of peptide from those in its presence (different concentrations); (b) Binding profiles of MV-HC to erythrocytes and PBMC, obtained by plotting the di-8-ANEPPS excitation ratio, $\mathrm{R}_{455 / 525}$, normalized to the initial value, as a function of the peptide concentration. 


\subsection{Aggregation Studies}

Self-association of peptide-lipid conjugates into higher order structures is modulated by amino acid sequence of the peptide and the nature of the lipid moiety $[56,57]$. The aggregation profile may directly influence the peptide's behavior in the physiological environment and influence antiviral activity. The fluorescent probe 8-anilinonaphthalene-1-sulfonic acid (ANS) was used to assess the peptide's propensity to self-assemble in aqueous solution. Interaction of ANS with hydrophobic sites causes an increase in its intrinsic fluorescence and a blue shift in the fluorescence emission maximum that correlates with peptide aggregation [70]. In the presence of ANS, increasing concentrations of MV-HC induced a blue shift in fluorescence emission, indicating the formation of aggregates (Figure 5a). A spectral maxima shift of approximately $80 \mathrm{~nm}$ was observed and was constant for concentrations above $20 \mu \mathrm{M}$. At the higher concentrations tested, ANS was mainly associated with the peptide aggregates. ANS fluorescence intensity as a function of the peptide concentration was also calculated (Figure $5 \mathrm{~b}$ ). At the highest concentration of peptide tested $(40 \mu \mathrm{M})$, the fluorescence intensity recorded was about 12-fold higher than the control obtained in the absence of peptide, which suggests that MV-HC aggregates extensively in solution.

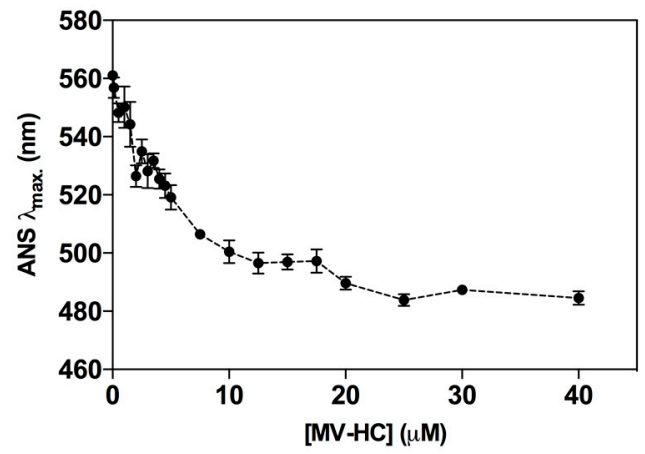

(a)

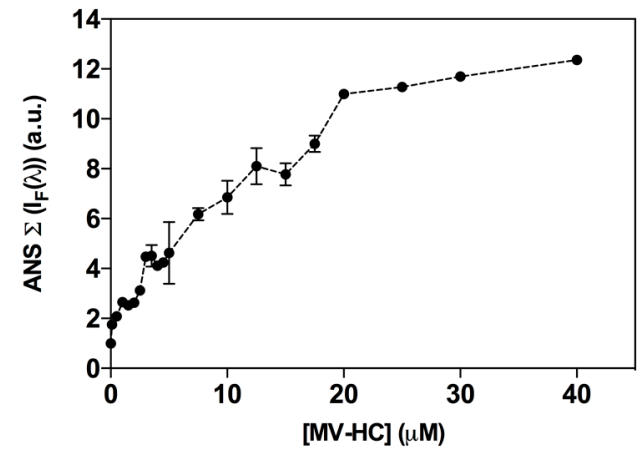

(b)

Figure 5. Aggregation of MV-HC evaluated by ANS fluorescence properties. The fluorescence emission maximum wavelength $\left(\lambda_{\max }\right)(\mathbf{a})$; and the fluorescence intensity spectrum integral $\left(\Sigma\left[\mathrm{I}_{\mathrm{F}}(\lambda)\right]\right)(\mathbf{b})$ were plotted as a function of MV-HC concentration.

The peptide aggregates were studied by DLS to determine their dimensions, presented here as hydrodynamic diameter $\left(\mathrm{D}_{\mathrm{H}}\right)$ [71]. The size of the aggregates is shown as a function of peptide concentration (Figure 6a) and time (Figure 6b). MV-HC aggregates even at the lowest concentration tested $(1 \mu \mathrm{M})$. The average size of the aggregates depends on peptide concentration, with larger $D_{H}$ values observed at higher concentrations. This behavior was also observed for dimers of HRC-derived peptides bearing a lipid moiety [57]. Nevertheless, the aggregates formed by MV-HC have a higher average hydrodynamic diameter. The peptide aggregation profile at $30 \mu \mathrm{M}$ over time (Figure $6 \mathrm{~b}$ ) starts with an increase in average diameter of the self-assembled particles, followed by a progressive decrease, which may indicate particle precipitation.

\subsection{Lipid-Conjugated Inhibitory Peptides Inhibit Cell-to-Cell Fusion}

We have previously identified a strong correlation between efficiency of inhibiting cell-to-cell fusion in vitro, and in vivo potency [72]. We have attributed the enhanced in vivo efficacy of specific peptides to their membrane insertion properties identified in vitro [52]. Here we describe the biophysical properties of $25 \mathrm{HC}$ conjugated peptide and we found different membrane interaction (i.e., a significantly more dynamic and improved interaction, as discussed above) than the previously described HRC2 (see Table 1) [57]. 


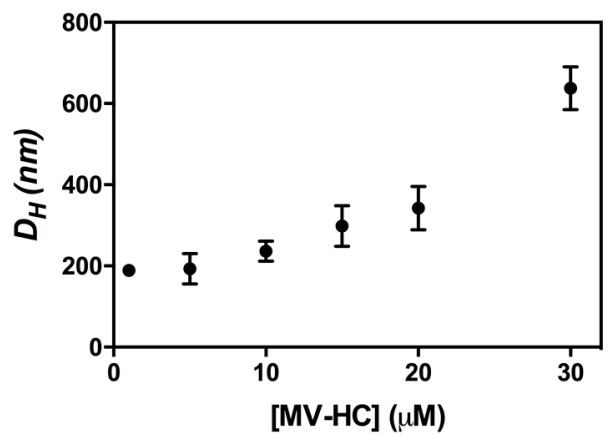

(a)

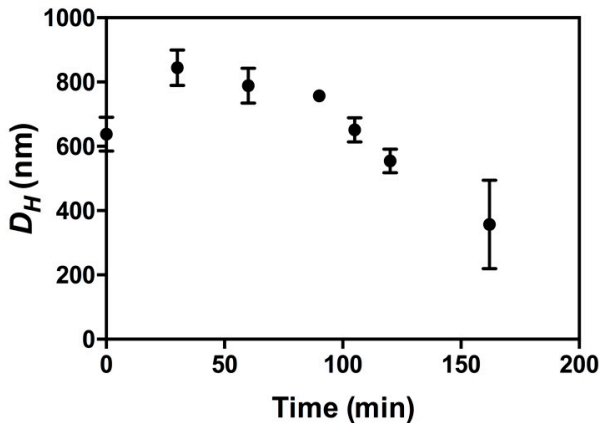

(b)

Figure 6. Aggregation of MV-HC evaluated by DLS: (a) average hydrodynamic diameter $\left(\mathrm{D}_{\mathrm{H}}\right)$ of the aggregates obtained at different MV-HC concentrations (time $=0 \mathrm{~min}$ ); and $(\mathbf{b}) \mathrm{D}_{\mathrm{H}}$ values of MV-HC $30 \mu \mathrm{M}$ followed over time.

Table 1. Sequences and modifications of MV HRC derived peptides.

\begin{tabular}{cc}
\hline Peptide & Sequences and Modifications \\
\hline MV HRC1 $^{\text {a }}$ & Ac-PPISLERLDVGTNLGNAIAKLEDAKELLESSDQILR \\
MV HRC2 $^{\text {a }}$ & - GSGSG-C- $\left(\mathrm{CH}_{2} \mathrm{CONH}_{2}\right)$ \\
& Ac-PPISLERLDVGTNLGNAIAKLEDAKELLESSDQILR \\
MV-HC & - GSGSG-C-(PEG4-Chol) \\
& Ac-PPISLERLDVGTNLGNAIAKLEDAKELLESSDQILR \\
\hline
\end{tabular}

${ }^{\text {a }}$ Described in $[54,57,73]$.

A similar dynamic interaction was observed for a HPIV3-derived peptide with a monodisperse PEG24 [56]. To determine whether the increased dynamic interaction affects in vitro potency, we directly measured fusion inhibition. To assess fusion, the fusion inhibitory peptides were assessed using a semi-quantitative $\beta$-galactosidase ( $\beta$-gal) complementation assay [74]. This assay measures the fusion of cells that express viral envelope glycoproteins (MV IC323 H/F) with cells that express the MV receptor SLAM-4 (Table 2).

Table 2. Fusion inhibition activity, at $24 \mathrm{~h}$, of MV HRC derived peptides.

\begin{tabular}{ccc}
\hline \multirow{2}{*}{ Peptide } & \multicolumn{2}{c}{ Fusion Inhibition } \\
\cline { 2 - 3 } & IC $_{\mathbf{5 0}}(\boldsymbol{\mu M})$ & IC $_{\mathbf{9 0}}(\boldsymbol{\mu M})$ \\
\hline MV HRC1 $^{\text {a }}$ & $>10$ & $>10$ \\
MV HRC2 $^{\text {a }}$ & $0.05 \pm 0.01$ & $\sim 10$ \\
MV-HC & $0.07 \pm 0.005$ & $\sim 0.3$ \\
\hline
\end{tabular}

Table 2 shows the peptide concentrations that blocked 50\% ( $\left.\mathrm{IC}_{50}\right)$ and $90 \%$ (IC 90 ) of fusion. As previously shown, the addition of a lipophilic moiety increased the antiviral potency of the HRC peptides, compared to the untagged peptides [57]. When we compared the $\mathrm{IC}_{50}$ of MV-HC vs. the previously described HRC2 (conjugated with PEG-Chol), the difference in potency was not statistically significant; however, the $\mathrm{IC}_{90}$ of MV-HC was several logs better than the HRC2. These data are in agreement with our previous findings that correlated peptide efficacy to membrane dynamic interactions [56]. 


\section{Discussion}

The MV-HC peptide conjugate comprises two antiviral moieties: a fusion inhibitory peptide based on the C-terminal heptad repeat of the MV F protein, and 25-hydroxycholesterol, a cholesterol derivative with activity against a variety of enveloped viruses [59]. MV-HC preserves the membrane interaction property conferred by cholesterol conjugation and increases the dynamicity of the kinetics of interaction in membranes representative of cell types relevant to MV infection [57] We hypothesize that the presence of $25 \mathrm{HC}$ influences the biophysical behavior of the peptide complex, which may be important not only for in vitro activity but also for in vivo antiviral properties [68,69].

In this study, we examined interaction of the MV-HC peptide with model membranes and with human blood cells. The peptide showed a preference for vesicles of POPC and a lower affinity for a mixture of POPC and cholesterol (2:1). With the ternary mixture-POPC:Chol:SM (1:1:1)—the peptide showed an interaction similar to that observed for pure POPC, with a dynamic kinetics of binding and rapid unbinding. In order to test peptide-cell membrane affinity, we used the probe di-8-ANEPPS to evaluate the interaction of the peptide with blood cell membranes. MV-HC interacts both with erythrocytes and PBMC, with an affinity comparable to that previously determined for enfuvirtide, an HIV fusion inhibitor in clinical use [66].

The aggregation profile of MV-HC was assessed by two different approaches. The fluorescence spectroscopy-based ANS method relies on the differences of the fluorescence spectra of this probe in the absence and presence of a range of peptide concentrations, promoted by the interaction of ANS with hydrophobic sites [75]. An increase in peptide concentration was followed by an increase in fluorescence intensity, as well as by a blue shift on fluorescence emission, both indicating the formation of peptide aggregates. DLS analysis of the aggregates showed that the peptide starts to aggregate at the lowest concentrations tested, and the size of the self-assembled particles depends on the peptide concentration. At the highest concentration $(30 \mu \mathrm{M})$, the average diameter of the particles decreased with time, which may suggest that the largest particles precipitate (becoming undetectable on the dynamic light scattering measurements), or reorganize into small aggregates. Such aggregation profile may eventually influence peptide insertion into the membrane and promote structural and dynamical changes in the lipid bilayer. Thus, the implication of peptide aggregation for peptide-lipid interaction is important to be clarified. Changes on the physical properties of the membranes, including membrane curvature and thickness, may influence the peptide's mechanism of action. Note however that in vivo, peptides will be dispersed in a membrane-rich environment and likely in contact with their target membranes.

Our results suggest that $25 \mathrm{HC}$ conjugation increases the interaction between the peptide and the membrane to a level similar to that observed for HRC-derived peptides bearing a PEG24 linker between the peptide and the cholesterol conjugate. The PEG24 linker, while bestowing increased antiviral potency, also conferred sensitivity to proteolytic degradation [56]. Even with equivalent antiviral potency for the MV-HC conjugate compared with PEG24-linked MV-HRC peptides, a decrease in sensitivity to proteolytic degradation would offer a significant advantage.

We previously showed that cholesterol-conjugated HRC-derived antiviral peptides distribute into the brain and prevent otherwise lethal measles encephalitis [54,57,73]. Most drugs translocate the blood-brain barrier (BBB) by transmembrane fusion [76]. However, the small size of a molecule or supramolecular assembly is not a guarantee of BBB crossing. In fact, just $2 \%$ of small molecules with a molecular mass under 500 Da can cross the brain capillary endothelium by simple diffusion, lipophilicity being one of the keys for success $[77,78]$. Nevertheless, a balance is needed regarding lipid solubility. While increased lipophilicity can favor the transport rate across BBB, it also can lower the amount of drug that reaches the cells behind the BBB, since it decreases their partition into the aqueous environment of the brain's interstitial fluid and increases their entrapment in the membranes [79]. An increase in lipid solubility promotes the uptake of the compound by the peripheral tissues, which can lead to lower concentrations of the compound available in the blood [76,80]. Thus, it will be of 
great interest to determine whether the altered hydrophobicity of $\mathrm{MV}-\mathrm{HC}$ conjugated $25 \mathrm{HC}$ enhances brain distribution.

\section{Material and Methods}

\subsection{Reagents}

MV-HC (Ac-PPISLERLDVGTNLGNAIAKLEDAKELLESSDQILR-GSGSG-C-25HC) was obtained by custom synthesis (American Peptide Company, Sunnyvale, CA, USA). HEPES, $\mathrm{NaCl}$ and DMSO were from Merck (Darmstadt, Germany). POPC (1-palmitoyl-2-oleoyl-sn-glycero-3-phosphocholine) and SM (egg sphingomyelin), were purchased from Avanti Polar Lipids (Alabaster, AL, USA), while cholesterol (Chol) and Pluronic F-127 were from Sigma (St. Louis, MO, USA). Biacore sensor chip regeneration reagents, namely, 3-[(3-cholamidopropyl)dimethylammonio]-1-propanesulfonate (CHAPS) and methanol, were also purchased from Sigma. The fluorescent probes 8-anilino-1-naphthalenesulfonic acid (ANS) and 4-(2-[6-(dioctylamino)-2-naphthalenyl]ethenyl)-1-(3-sulfopropyl)pyridinium inner salt (di-8-ANEPPS) were from Merck (Darmstadt, Germany) and Invitrogen (Carlsbad, CA, USA), respectively. Lymphoprep was from Axis-Shield (Oslo, Norway).

The genes of MV IC323 wt H and wt F were codon optimized, synthesized and subcloned into the mammalian expression vector pCAGGS. The construct for SLAM was commercially acquired.

\subsection{Sample Preparation}

The lyophilized peptide was solubilized in DMSO up to $40 \mathrm{mg} / \mathrm{mL}$, sonicated in a water bath for $5 \mathrm{~min}$, and stored at $-20^{\circ} \mathrm{C}$. Working peptide samples at defined final concentrations were solubilized from stock solutions in $10 \mathrm{mM}$ HEPES $150 \mathrm{mM} \mathrm{NaCl}$ buffer, $\mathrm{pH}$ 7.4. The final DMSO content was maintained at $2 \%(v / v)$ in all experiments. Working peptide samples were sonicated in an ultrasonic bath for 2 to 5 min before use.

Small unilamellar vesicles (SUV) were prepared as previously described [81]. The lipid mixture was first solubilized in chloroform in a round-bottom flask. The solvent was evaporated under nitrogen flow until a thin lipid film was formed on the flask wall. The lipid film was further dried under vacuum overnight. A multilamellar vesicles (MLV) suspension was obtained after rehydration with the sample buffer and a series of 10 freeze-thaw cycles. The MLV suspension was extruded through a $50 \mathrm{~nm}$-pore-size Nuclepore polycarbonate membrane purchased from Whatman/GE Healthcare (Maidstone, UK) using a LiposoFast-Basic plus Stabilizer setup from Avestin (Mannheim, Germany). This allowed the reorganization of MLVs into SUV. POPC, POPC:Chol (2:1), and POPC:Chol:SM (1:1:1) mixtures were prepared.

\subsection{Surface Plasmon Resonance}

For surface plasmon resonance (SPR) measurements, $10 \mathrm{mM}$ HEPES $150 \mathrm{mM} \mathrm{NaCl}, \mathrm{pH}$ 7.4, with $2 \%(v / v)$ DMSO was used as running buffer to match the peptide and lipid sample buffer composition. Experiments were performed in a GE Healthcare Biacore X100 (GE Healthcare Life Sciences, Buckinghamshire, UK). The system was primed at least three times with running buffer before starting an experiment. L1 sensor chips, designed for lipid binding assays, were used in all experiments. Immediately before each assay, the sensor chip surface was rinsed with three injections of 20 mM CHAPS. To prepare the lipid surface, a $1 \mathrm{mM}$ POPC, POPC:Chol (2:1) or POPC:Chol:SM (1:1:1) SUV sample was injected over the sensor chip at a $2 \mu \mathrm{L} / \mathrm{min}$ flow speed for $2400 \mathrm{~s}(40 \mathrm{~min}$ ). Loosely bound vesicles were removed with a $36 \mathrm{~s}$ injection of $10 \mathrm{mM} \mathrm{NaOH}$, at $50 \mu \mathrm{L} / \mathrm{min}$. MV-HC samples, with concentrations between 1 and $30 \mu \mathrm{M}$, were injected over the deposited lipid surface at a $5 \mu \mathrm{L} / \mathrm{min}$ flow speed during $200 \mathrm{~s}$. Each sample was allowed a $600 \mathrm{~s}$ (10 min) unbinding time after injection stopped. After each run, the sensor chip surface was regenerated with sequential injections of $20 \mathrm{mM}$ CHAPS ( $5 \mu \mathrm{L} / \mathrm{min}$ for $60 \mathrm{~s}), 0.5 \%(w / v)$ SDS $(5 \mu \mathrm{L} / \mathrm{min}$ for $60 \mathrm{~s}), 10 \mathrm{mM} \mathrm{NaOH}$ with 
$20 \%(\mathrm{v} / \mathrm{v})$ methanol (50 $\mu \mathrm{L} / \mathrm{min}$ for $36 \mathrm{~s})$, and $10 \mathrm{mM} \mathrm{NaOH}(50 \mu \mathrm{L} / \mathrm{min}$ for $36 \mathrm{~s})$. Response values were monitored to ensure effective surface regeneration. To analyze the SPR membrane interaction data, the SUV deposition on the sensor chip surface and the response values for peptide binding to lipid were converted into units of moles per area and used to calculate the respective peptide-to-lipid molar ratio. To perform these calculations, we considered 1 response unit (RU) to be approximately $1 \mathrm{pg} / \mathrm{mm}^{2}$ of peptide or lipid, as previously described [82].

\subsection{Membrane Dipole Potential Assessment with Di-8-ANEPPS}

Human blood samples were obtained from healthy volunteers, with their previous written informed consent, at Instituto Português do Sangue (Lisbon, Portugal), as approved by the joint Ethics Committee of Faculdade de Medicina da Universidade de Lisboa and Santa Maria Hospital. Isolation of erythrocytes and peripheral blood mononuclear cells (PBMC), as well as the labeling of these cells with di-8-ANEPPS, were performed as previously described [66,67]. In the case of erythrocyte isolation, blood samples were centrifuged at $1200 \times \mathrm{g}$ during $10 \mathrm{~min}$ to remove plasma and the buffy-coat. Erythrocytes were washed twice with the working buffer and then incubated at a $1 \%$ suspension in buffer supplemented with $0.05 \%(m / v)$ Pluronic F-127 (Sigma) and di-8-ANEPPS $10 \mu \mathrm{M}$. PBMC were isolated by density gradient using Lymphoprep and counted in a MOXI Z Mini Automated Cell Counter (Orflo Technologies, Ketchum, ID, USA). They were then incubated at a density of 3000 cells $/ \mathrm{mL}$ in Pluronic-supplemented buffer with di-8-ANEPPS. Cells were incubated with the fluorescent probe during $1 \mathrm{~h}$ at room temperature, with gentle agitation, protected from light. Unbound probe was washed with Pluronic-free buffer on two centrifugation cycles.

Excitation spectra and the ratio of intensities at the excitation wavelengths of 455 and $525 \mathrm{~nm}$ $\left(\mathrm{R}=\mathrm{I}_{455} / \mathrm{I}_{525}\right)$ were obtained with emission set at $670 \mathrm{~nm}$ to avoid membrane fluidity-related artifacts $[83,84]$. Excitation and emission slits for these measurements were set to 5 and $10 \mathrm{~nm}$, respectively.

\subsection{ANS Fluorescence Studies}

For the peptide aggregation studies, a $12.8 \mu \mathrm{M}$ 8-anilinonaphthalene-1-sulfonic acid (ANS) solution was titrated with the MV-HC peptide up to final concentrations between 0 and $40 \mu \mathrm{M}$. For each sample, fluorescence emission spectra were collected between 400 and $600 \mathrm{~nm}$ (excitation wavelength $=369 \mathrm{~nm}$ ) in a Varian Cary Eclipse fluorescence spectrophotometer (Mulgrave, Australia). Excitation and emission slits were 5 and $10 \mathrm{~nm}$, respectively. A $10 \mathrm{~min}$ incubation time was allowed before each measurement. The fluorescence emission intensity values were corrected for dilution and background noise. The maximum emission wavelength, $\lambda_{\max }$, and the spectrum integral, $\left[I_{F}(\lambda)\right]$, were determined for each spectrum.

\subsection{Dynamic Light Scattering}

For dynamic light scattering (DLS), MV-HC peptide solutions with concentrations ranging from 1 to $30 \mu \mathrm{M}$ were prepared as described above and incubated at $25^{\circ} \mathrm{C}$ for $5 \mathrm{~min}$ before each measurement of particle size. Measurements were performed on a Malvern Zetasizer Nano ZS (Malvern Instruments, Malvern, UK) and consisted of 15 individual runs, each corresponding to an averaged autocorrelation curve obtained from at least 12 repeated sample scans. The diffusion coefficient (D) values were calculated from autocorrelation curves using a CONTIN-based method [85]. D values were used to determine averaged hydrodynamic diameter $\left(\mathrm{D}_{\mathrm{H}}\right)$ profiles through the Stokes-Einstein equation [86].

\subsection{Cells}

293T cells (human kidney epithelial cells) were grown in Dulbecco's modified Eagle's medium (DMEM) (GIBCO; Invitrogen, Carlsbad, CA, USA) supplemented with $10 \%$ fetal bovine serum and antibiotics, in $5 \% \mathrm{CO}_{2}$. The Vero-SLAM culture medium was supplemented with geneticin. 


\subsection{Transient Expression of $H$ and $F$ Genes}

Transfections were performed in 293T cells according to the Lipofectamine 2000 manufacturer's protocols (Invitrogen, Carlsbad, CA, USA).

\section{9. $\beta$-Galactosidase Complementation-Based Fusion Assay}

This assay was performed as described previously [74,87]. Briefly, 293T cells transiently transfected with SLAM and the omega reporter subunit were incubated with cells coexpressing viral glycoproteins (MV H and MV F) and the alpha reporter subunit.

\subsection{Data Analysis}

The fitting of the experimental data with the equations mentioned in this article was done by non-linear regression using Prism 5 (GraphPad Software, La Jolla, CA, USA). Error bars on data presentation represent the standard error of mean (SEM).

Acknowledgments: This work was supported by Fundação para a Ciência e Tecnologia-Ministério da Ciência, Tecnologia e Ensino Superior (FCT-MCTES, Portugal) grant PTDC/BBB-BQB/3494/2014, and NIH AI119762, AI121349, and NS091263 to M.P. B.G. also acknowledges FCT-MCTES fellowship SPRH/BD/52431/2013.

Author Contributions: B.G. conducted the biophysical experiments, analyzed the results, and wrote the manuscript. M.P. conducted the fusion assay. N.C.S. and M.P. conceived the idea for the project and wrote the manuscript with B.G. All authors contributed for the final version of the manuscript.

Conflicts of Interest: The authors declare no conflict of interest.

\section{References}

1. De Vries, R.D.; Duprex, W.P.; De Swart, R.L. Morbillivirus infections: An introduction. Viruses 2015, 7, 699-706. [CrossRef] [PubMed]

2. Progress Toward Regional Measles Elimination-Worldwide. 2000-2015. Available online: https:/ / www. cdc.gov/mmwr/volumes/65/wr/mm6544a6.htm (accessed on 10 July 2017).

3. Holzmann, H.; Hengel, H.; Tenbusch, M.; Doerr, H.W. Eradication of measles: Remaining challenges. Med. Microbiol. Immunol. 2016, 205, 201-208. [CrossRef] [PubMed]

4. Measles Outbreaks Across Europe Threaten Progress Towards Elimination. Available online: http:/ / www.euro.who.int/en/media-centre/sections/press-releases/2017/measles-outbreaks-acrosseurope-threaten-progress-towards-elimination (accessed on 10 July 2017).

5. De Serres, G.; Boulianne, N.; Defay, F.; Brousseau, N.; Benoit, M.; Lacoursiere, S.; Guillemette, F.; Soto, J.; Ouakki, M.; Ward, B.J.; et al. Higher risk of measles when the first dose of a 2-dose schedule of measles vaccine is given at 12-14 months versus 15 months of age. Clin. Infect. Dis. 2012, 55, 394-402. [CrossRef] [PubMed]

6. Haralambieva, I.H.; Ovsyannikova, I.G.; O’Byrne, M.; Pankratz, V.S.; Jacobson, R.M.; Poland, G.A. A large observational study to concurrently assess persistence of measles specific B-cell and T-cell immunity in individuals following two doses of MMR vaccine. Vaccine 2011, 29, 4485-4491. [CrossRef] [PubMed]

7. Chen, C.J.; Lee, P.I.; Hsieh, Y.C.; Chen, P.Y.; Ho, Y.H.; Chang, C.J.; Liu, D.P.; Chang, F.Y.; Chiu, C.H.; Huang, Y.C.; et al. Waning population immunity to measles in Taiwan. Vaccine 2012, 30, 6721-6727. [CrossRef] [PubMed]

8. Wendorf, K.A.; Winter, K.; Zipprich, J.; Schechter, R.; Hacker, J.K.; Preas, C.; Cherry, J.D.; Glaser, C.; Harriman, K. Subacute sclerosing panencephalitis: The devastating measles complication that might be more common than previously estimated. Clin. Infect. Dis. 2017, 65, 226-232. [CrossRef] [PubMed]

9. Fox, A.; Hung, T.M.; Wertheim, H.; Hoa le, N.M.; Vincent, A.; Lang, B.; Waters, P.; Ha, N.H.; Trung, N.V.; Farrar, J.; et al. Acute measles encephalitis in partially vaccinated adults. PLoS ONE 2013, 8, e71671. [CrossRef] [PubMed]

10. Hardie, D.R.; Albertyn, C.; Heckmann, J.M.; Smuts, H.E. Molecular characterisation of virus in the brains of patients with measles inclusion body encephalitis (MIBE). Virol. J. 2013, 10, 283. [CrossRef] [PubMed] 
11. Mahil, S.K.; Fleming, J.; Robson, A.; Sarkany, R. Measles in a previously vaccinated human immunodeficiency virus-positive adult. Clin. Exp. Dermatol. 2014, 39, 117-118. [CrossRef] [PubMed]

12. O'Donnell, L.A.; Rall, G.F. Blue moon neurovirology: The merits of studying rare CNS diseases of viral origin. J. Neuroimmune Pharmacol. 2010, 5, 443-455. [CrossRef] [PubMed]

13. Young, V.A.; Rall, G.F. Making it to the synapse: Measles virus spread in and among neurons. Curr. Top. Microbiol. Immunol. 2009, 330, 3-30. [PubMed]

14. Makhortova, N.R.; Askovich, P.; Patterson, C.E.; Gechman, L.A.; Gerard, N.P.; Rall, G.F. Neurokinin-1 enables measles virus trans-synaptic spread in neurons. Virology 2007, 362, 235-244. [CrossRef] [PubMed]

15. Reuter, D.; Schneider-Schaulies, J. Measles virus infection of the CNS: Human disease, animal models, and approaches to therapy. Med. Microbiol. Immunol. 2010, 199, 261-271. [CrossRef] [PubMed]

16. Chiu, M.H.; Meatherall, B.; Nikolic, A.; Cannon, K.; Fonseca, K.; Joseph, J.T.; MacDonald, J.; Pabbaraju, K.; Tellier, R.; Wong, S.; et al. Subacute sclerosing panencephalitis in pregnancy. Lancet Infect. Dis. 2016, 16, 366-375. [CrossRef]

17. De Vries, R.D.; Mesman, A.W.; Geijtenbeek, T.B.; Duprex, W.P.; De Swart, R.L. The pathogenesis of measles. Curr. Opin. Virol. 2012, 2, 248-255. [CrossRef] [PubMed]

18. Ferreira, C.S.; Frenzke, M.; Leonard, V.H.; Welstead, G.G.; Richardson, C.D.; Cattaneo, R. Measles virus infection of alveolar macrophages and dendritic cells precedes spread to lymphatic organs in transgenic mice expressing human signaling lymphocytic activation molecule (SLAM, CD150). J. Virol. 2010, 84, 3033-3042. [CrossRef] [PubMed]

19. Avota, E.; Koethe, S.; Schneider-Schaulies, S. Membrane dynamics and interactions in measles virus dendritic cell infections. Cell Microbiol. 2013, 15, 161-169. [CrossRef] [PubMed]

20. Koethe, S.; Avota, E.; Schneider-Schaulies, S. Measles virus transmission from dendritic cells to T cells: Formation of synapse-like interfaces concentrating viral and cellular components. J. Virol. 2012, 86, 9773-9781. [CrossRef] [PubMed]

21. Lemon, K.; de Vries, R.D.; Mesman, A.W.; McQuaid, S.; van Amerongen, G.; Yuksel, S.; Ludlow, M.; Rennick, L.J.; Kuiken, T.; Rima, B.K.; et al. Early target cells of measles virus after aerosol infection of non-human primates. PLoS Pathog. 2011, 7, e1001263. [CrossRef] [PubMed]

22. Yanagi, Y.; Ono, N.; Tatsuo, H.; Hashimoto, K.; Minagawa, H. Measles virus receptor SLAM (CD150). Virology 2002, 299, 155-161. [CrossRef] [PubMed]

23. Yanagi, Y.; Takeda, M.; Ohno, S.; Hashiguchi, T. Measles virus receptors. Curr. Top. Microbiol. Immunol. 2009, 329, 13-30. [PubMed]

24. Hashiguchi, T.; Maenaka, K.; Yanagi, Y. Measles virus hemagglutinin: Structural insights into cell entry and measles vaccine. Front. Microbiol. 2011, 2, 247. [CrossRef] [PubMed]

25. Tatsuo, H.; Ono, N.; Tanaka, K.; Yanagi, Y. SLAM (CDw150) is a cellular receptor for measles virus. Nature 2000, 406, 893-897. [PubMed]

26. Muhlebach, M.D.; Mateo, M.; Sinn, P.L.; Prufer, S.; Uhlig, K.M.; Leonard, V.H.; Navaratnarajah, C.K.; Frenzke, M.; Wong, X.X.; Sawatsky, B.; et al. Adherens junction protein nectin-4 is the epithelial receptor for measles virus. Nature 2011, 480, 530-553. [CrossRef] [PubMed]

27. Noyce, R.S.; Bondre, D.G.; Ha, M.N.; Lin, L.T.; Sisson, G.; Tsao, M.S.; Richardson, C.D. Tumor cell marker PVRL4 (nectin 4) is an epithelial cell receptor for measles virus. PLoS Pathog. 2011, 7, e1002240. [CrossRef] [PubMed]

28. Singh, B.K.; Li, N.; Mark, A.C.; Mateo, M.; Cattaneo, R.; Sinn, P.L. Cell-to-cell contact and nectin-4 govern spread of measles virus from primary human myeloid cells to primary human airway epithelial cells. J. Virol. 2016, 90, 6808-6817. [CrossRef] [PubMed]

29. Lin, L.T.; Richardson, C.D. The host cell receptors for measles virus and their interaction with the viral hemagglutinin $(\mathrm{H})$ protein. Viruses 2016, 8, 250. [CrossRef] [PubMed]

30. Laksono, B.M.; De Vries, R.D.; McQuaid, S.; Duprex, W.P.; De Swart, R.L. Measles virus host invasion and pathogenesis. Viruses 2016, 8, E210. [CrossRef] [PubMed]

31. Delpeut, S.; Sawatsky, B.; Wong, X.X.; Frenzke, M.; Cattaneo, R.; Von Messling, V. Nectin-4 interactions govern measles virus virulence in a new model of pathogenesis, the squirrel monkey (Saimiri sciureus). J. Virol. 2017, 91, e02490-16. [CrossRef] [PubMed]

32. Yin, H.S.; Paterson, R.G.; Wen, X.; Lamb, R.A.; Jardetzky, T.S. Structure of the uncleaved ectodomain of the paramyxovirus (hPIV3) fusion protein. Proc. Natl. Acad. Sci. USA 2005, 102, 9288-9293. [CrossRef] [PubMed] 
33. Lamb, R.A.; Paterson, R.G.; Jardetzky, T.S. Paramyxovirus membrane fusion: Lessons from the F and HN atomic structures. Virology 2006, 344, 30-37. [CrossRef] [PubMed]

34. Yin, H.S.; Wen, X.; Paterson, R.G.; Lamb, R.A.; Jardetzky, T.S. Structure of the parainfluenza virus 5 F protein in its metastable, prefusion conformation. Nature 2006, 439, 38-44. [CrossRef] [PubMed]

35. Harrison, S.C. Viral membrane fusion. Nat. Struct. Mol. Biol. 2008, 15, 690-698. [CrossRef] [PubMed]

36. Chang, A.; Dutch, R.E. Paramyxovirus fusion and entry: Multiple paths to a common end. Viruses 2012, 4, 613-636. [CrossRef] [PubMed]

37. Plemper, R.K.; Brindley, M.A.; Iorio, R.M. Structural and mechanistic studies of measles virus illuminate paramyxovirus entry. PLoS Pathog. 2011, 7, e1002058. [CrossRef] [PubMed]

38. White, J.M.; Delos, S.E.; Brecher, M.; Schornberg, K. Structures and mechanisms of viral membrane fusion proteins: Multiple variations on a common theme. Crit. Rev. Biochem. Mol. Biol. 2008, 43, 189-219. [CrossRef] [PubMed]

39. Sapir, A.; Avinoam, O.; Podbilewicz, B.; Chernomordik, L.V. Viral and developmental cell fusion mechanisms: Conservation and divergence. Dev. Cell. 2008, 14, 11-21. [CrossRef] [PubMed]

40. Pessi, A.; Langella, A.; Capito, E.; Ghezzi, S.; Vicenzi, E.; Poli, G.; Ketas, T.; Mathieu, C.; Cortese, R.; Horvat, B.; et al. A general strategy to endow natural fusion-protein-derived peptides with potent antiviral activity. PLOS ONE 2012, 7, e36833. [CrossRef] [PubMed]

41. Vigant, F.; Lee, B. Hendra and nipah infection: Pathology, models and potential therapies. Infect. Disord. Drug Targets 2011, 11, 315-336. [CrossRef] [PubMed]

42. Schmidt, A.G.; Yang, P.L.; Harrison, S.C. Peptide inhibitors of flavivirus entry derived from the E protein stem. J. Virol. 2010, 84, 12549-12554. [CrossRef] [PubMed]

43. Steffen, D.L.; Xu, K.; Nikolov, D.B.; Broder, C.C. Henipavirus mediated membrane fusion, virus entry and targeted therapeutics. Viruses 2012, 4, 280-309. [CrossRef] [PubMed]

44. Tan, J.J.; Ma, X.T.; Liu, C.; Zhang, X.Y.; Wang, C.X. The current status and challenges in the development of fusion inhibitors as therapeutics for HIV-1 infection. Curr. Pharm. Des. 2012, 19, 1810-1817. [CrossRef]

45. Miyamoto, F.; Kodama, E.N. Novel HIV-1 fusion inhibition peptides: Designing the next generation of drugs. Antivir. Chem. Chemother. 2012, 22, 151-158. [CrossRef] [PubMed]

46. Eckert, D.M.; Kim, P.S. Mechanisms of viral membrane fusion and its inhibition. Annu. Rev. Biochem. 2001, 70, 777-810. [CrossRef] [PubMed]

47. Eckert, D.M.; Kim, P.S. Design of potent inhibitors of HIV-1 entry from the gp41 N-peptide region. Proc. Natl. Acad. Sci. USA 2001, 98, 11187-11192. [CrossRef] [PubMed]

48. Lee, K.K.; Pessi, A.; Gui, L.; Santoprete, A.; Talekar, A.; Moscona, A.; Porotto, M. Capturing a fusion intermediate of influenza hemagglutinin with a cholesterol-conjugated peptide, a new antiviral strategy for influenza virus. J. Biol. Chem. 2011, 286, 42141-42149. [CrossRef] [PubMed]

49. Porotto, M.; Carta, P.; Deng, Y.; Kellogg, G.E.; Whitt, M.; Lu, M.; Mungall, B.A.; Moscona, A. Molecular determinants of antiviral potency of paramyxovirus entry inhibitors. J. Virol. 2007, 81, 10567-10574. [CrossRef] [PubMed]

50. Lambert, D.M.; Barney, S.; Lambert, A.L.; Guthrie, K.; Medinas, R.; Davis, D.E.; Bucy, T.; Erickson, J.; Merutka, G.; Petteway, S.R., Jr. Peptides from conserved regions of paramyxovirus fusion (F) proteins are potent inhibitors of viral fusion. Proc. Natl. Acad. Sci. USA 1996, 93, 2186-2191. [CrossRef] [PubMed]

51. Porotto, M.; Yokoyama, C.C.; Orefice, G.; Kim, H.S.; Aljofan, M.; Mungall, B.A.; Moscona, A. Kinetic dependence of paramyxovirus entry inhibition. J. Virol. 2009, 83, 6947-6951. [CrossRef] [PubMed]

52. Porotto, M.; Yokoyama, C.C.; Palermo, L.M.; Mungall, B.; Aljofan, M.; Cortese, R.; Pessi, A.; Moscona, A. Viral entry inhibitors targeted to the membrane site of action. J. Virol. 2010, 84, 6760-6768. [CrossRef] [PubMed]

53. Porotto, M.; Rockx, B.; Yokoyama, C.C.; Talekar, A.; Devito, I.; Palermo, L.M.; Liu, J.; Cortese, R.; Lu, M.; Feldmann, H.; et al. Inhibition of Nipah virus infection in vivo: Targeting an early stage of paramyxovirus fusion activation during viral entry. PLoS Pathog. 2010, 6, e1001168. [CrossRef] [PubMed]

54. Welsch, J.C.; Talekar, A.; Mathieu, C.; Pessi, A.; Moscona, A.; Horvat, B.; Porotto, M. Fatal measles virus infection prevented by brain-penetrant fusion inhibitors. J. Virol. 2013, 87, 13785-13794. [CrossRef] [PubMed]

55. Palmer, S.G.; DeVito, I.; Jenkins, S.G.; Niewiesk, S.; Porotto, M.; Moscona, A. Circulating clinical strains of human parainfluenza virus reveal viral entry requirements for in vivo infection. J. Virol. 2014, 88, 13495-13502. [CrossRef] [PubMed] 
56. Mathieu, C.; Augusto, M.T.; Niewiesk, S.; Horvat, B.; Palermo, L.M.; Sanna, G.; Madeddu, S.; Huey, D.; Castanho, M.A.; Porotto, M.; et al. Broad spectrum antiviral activity for paramyxoviruses is modulated by biophysical properties of fusion inhibitory peptides. Sci. Rep. 2017, 7, 43610. [PubMed]

57. Figueira, T.N.; Palermo, L.M.; Veiga, A.S.; Huey, D.; Alabi, C.A.; Santos, N.C.; Welsch, J.C.; Mathieu, C.; Horvat, B.; Niewiesk, S.; et al. In vivo efficacy of measles virus fusion protein-derived peptides is modulated by properties of self-assembly and membrane residence. J. Virol. 2016, 91, e01554-16. [PubMed]

58. Chen, Y.; Wang, S.; Yi, Z.; Tian, H.; Aliyari, R.; Li, Y.; Chen, G.; Liu, P.; Zhong, J.; Chen, X.; et al. Interferon-inducible cholesterol-25-hydroxylase inhibits hepatitis $\mathrm{C}$ virus replication via distinct mechanisms. Sci. Rep. 2014, 4, 7242. [CrossRef] [PubMed]

59. Liu, S.Y.; Aliyari, R.; Chikere, K.; Li, G.M.; Marsden, M.D.; Smith, J.K.; Pernet, O.; Guo, H.T.; Nusbaum, R.; Zack, J.A.; et al. Interferon-inducible cholesterol-25-hydroxylase broadly inhibits viral entry by production of 25-hydroxycholesterol. Immunity 2013, 38, 92-105. [CrossRef] [PubMed]

60. Bauman, D.R.; Bitmansour, A.D.; McDonald, J.G.; Thompson, B.M.; Liang, G.S.; Russell, D.W. 25-Hydroxycholesterol secreted by macrophages in response to toll-like receptor activation suppresses immunoglobulin A production. Proc. Natl. Acad. Sci. USA 2009, 106, 16764-16769. [CrossRef] [PubMed]

61. Cyster, J.G.; Dang, E.V.; Reboldi, A.; Yi, T. 25-Hydroxycholesterols in innate and adaptive immunity. Nat. Rev. Immunol. 2014, 14, 731-743. [CrossRef] [PubMed]

62. Besenicar, M.; Macek, P.; Lakey, J.H.; Anderluh, G. Surface plasmon resonance in protein-membrane interactions. Chem. Phys. Lipids 2006, 141, 169-178. [CrossRef] [PubMed]

63. Manie, S.N.; de Breyne, S.; Vincent, S.; Gerlier, D. Measles virus structural components are enriched into lipid raft microdomains: A potential cellular location for virus assembly. J. Virol. 2000, 74, 305-311. [CrossRef] [PubMed]

64. Vincent, S.; Gerlier, D.; Manie, S.N. Measles virus assembly within membrane rafts. J. Virol. 2000, 74, 9911-9915. [CrossRef] [PubMed]

65. Hashimoto, S. Real-Time Analysis of Biomolecular Interactions_Principles of BIACORE; Nagata, K., Handa, H., Eds.; Springer: Tokyo, Japan, 2000; pp. 23-30.

66. Matos, P.M.; Castanho, M.A.; Santos, N.C. HIV-1 fusion inhibitor peptides enfuvirtide and T-1249 interact with erythrocyte and lymphocyte membranes. PLoS ONE 2010, 5, e9830. [CrossRef] [PubMed]

67. Matos, P.M.; Franquelim, H.G.; Castanho, M.A.; Santos, N.C. Quantitative assessment of peptide-lipid interactions. Ubiquitous fluorescence methodologies. Biochim. Biophys. Acta. 2010, 1798, 1999-2012. [CrossRef] [PubMed]

68. Augusto, M.T.; Hollmann, A.; Castanho, M.A.; Porotto, M.; Pessi, A.; Santos, N.C. Improvement of HIV fusion inhibitor C34 efficacy by membrane anchoring and enhanced exposure. J. Antimicrob. Chemother. 2014, 69, 1286-1297. [CrossRef] [PubMed]

69. Hollmann, A.; Matos, P.M.; Augusto, M.T.; Castanho, M.A.; Santos, N.C. Conjugation of cholesterol to HIV-1 fusion inhibitor C34 increases peptide-membrane interactions potentiating its action. PLoS ONE 2013, 8, e60302. [CrossRef] [PubMed]

70. Slavik, J. Anilinonaphthalene sulfonate as a probe of membrane composition and function. Biochim. Biophys. Acta 1982, 694, 1-25. [CrossRef]

71. Stetefeld, J.; McKenna, S.A.; Patel, T.R. Dynamic light scattering: A practical guide and applications in biomedical sciences. Biophys. Rev. 2016, 8, 409-427. [CrossRef] [PubMed]

72. Jurgens, E.M.; Mathieu, C.; Palermo, L.M.; Hardie, D.; Horvat, B.; Moscona, A.; Porotto, M. Measles fusion machinery is dysregulated in neuropathogenic variants. MBio 2015, 6, e2528-14. [CrossRef] [PubMed]

73. Mathieu, C.; Huey, D.; Jurgens, E.; Welsch, J.C.; DeVito, I.; Talekar, A.; Horvat, B.; Niewiesk, S.; Moscona, A.; Porotto, M. Prevention of measles virus infection by intranasal delivery of fusion inhibitor peptides. J. Virol. 2015, 89, 1143-1155. [CrossRef] [PubMed]

74. Moosmann, P.; Rusconi, S. Alpha complementation of LacZ in mammalian cells. Nucleic Acids Res. 1996, 24, 1171-1172. [CrossRef] [PubMed]

75. Hawe, A.; Sutter, M.; Jiskoot, W. Extrinsic fluorescent dyes as tools for protein characterization. Pharm. Res. 2008, 25, 1487-1499. [CrossRef] [PubMed]

76. Oldendorf, W.H. Lipid solubility and drug penetration of the blood brain barrier. Proc. Soc. Exp. Biol. Med. 1974, 147, 813-815. [CrossRef] [PubMed] 
77. Loureiro, J.A.; Gomes, B.; Coelho, M.A.; do Carmo Pereira, M.; Rocha, S. Targeting nanoparticles across the blood-brain barrier with monoclonal antibodies. Nanomedicine 2014, 9, 709-722. [CrossRef] [PubMed]

78. Pardridge, W.M. The blood-brain barrier: Bottleneck in brain drug development. NeuroRx 2005, 2, 3-14. [CrossRef] [PubMed]

79. Liu, X.; Testa, B.; Fahr, A. Lipophilicity and its relationship with passive drug permeation. Pharm. Res. 2011, 28, 962-977. [CrossRef] [PubMed]

80. Greig, N.H.; Brossi, A.; Pei, X.F.; Ingram, D.K.; Soncrant, T.T. Designing Drugs for Optimal Nervous System Activity. In New Concepts of a Blood-Brain Barrier; Greenwood, J., Begley, D.J., Segal, M.B., Eds.; Springer: Boston, MA, USA, 1995; pp. 251-264.

81. Vemuri, S.; Rhodes, C.T. Preparation and characterization of liposomes as therapeutic delivery systems: A review. Pharm. Acta Helv. 1995, 70, 95-111. [CrossRef]

82. Craik, D.J.; Henriques, S.T.; Mylne, J.S.; Wang, C.K. Cyclotide isolation and characterization. Methods Enzymol. 2012, 516, 37-62. [PubMed]

83. Gross, E.; Bedlack, R.S.; Loew, L.M. Dual-wavelength ratiometric fluorescence measurement of the membrane dipole potential. Biophys. J. 1994, 67, 208-216. [CrossRef]

84. Clarke, R.J.; Kane, D.J. Optical detection of membrane dipole potential: Avoidance of fluidity and dye-induced effects. Biochim. Biophys. Acta-Biomembr. 1997, 1323, 223-239. [CrossRef]

85. Provencher, S. CONTIN: A general purpose constrained regularization program for inverting noisy linear algebraic and integral equations. Comput. Phys. Commun. 1982, 27, 13. [CrossRef]

86. Berne, B.J.; Pecora, R. Dynamic Light Scattering: With Applications to Chemistry, Biology, and Physics; Dover Publications: Mineola, NY, USA, 1990.

87. Porotto, M.; Fornabaio, M.; Kellogg, G.E.; Moscona, A. A second receptor binding site on human parainfluenza virus type 3 hemagglutinin-neuraminidase contributes to activation of the fusion mechanism. J. Virol. 2007, 81, 3216-3228. [CrossRef] [PubMed]

Sample Availability: Samples of the compounds are not available from the authors.

(C) 2017 by the authors. Licensee MDPI, Basel, Switzerland. This article is an open access article distributed under the terms and conditions of the Creative Commons Attribution (CC BY) license (http://creativecommons.org/licenses/by/4.0/). 